\title{
ANALISIS FAKTOR- FAKTOR YANG MEMENGARUHI NILAI PERUSAHAAN DI SEKTOR PROPERTI DAN REAL ESTATE TERDAFTAR DI BURSA EFEK INDONESIA PADA TAHUN 2014 - 2018
}

\author{
Andy \\ Program Studi Magister Manajemen Universitas Tarumanagara \\ andyfu@y7mail.com \\ Suwinto Johan \\ Program Studi Magister Manajemen Universitas Tarumanagara \\ Masuk : 07-12-2019, revisi : 20-12-2019 diterima untuk diterbitkan : 21-12-2019
}

\begin{abstract}
The main issues examined in this study are the effect of profitability, capital structure, and firm size on firm value. The type of research is using descriptive research. The population in this study are all property and real estate companies listed on the Indonesia Stock Exchange. The sampling technique was determined by purposive sampling that 24 companies could be sampled. All the data in this study are secondary data. The dependent variable is firm value and the independent variable is the profitability, capital structure, and firm size. From the results of hypothesis testing, it is found that: First, profitability has a significant effect on firm value with a sig value of $0,000<\alpha=0.05$. Second, capital structure affects the value of the company with a sig value of $0.024<\alpha=0.05$. Third, the size of the company affects the value of the company with a sig value of $0.699>\alpha=0.05$. Fourth, profitability, capital structure, and company size significantly influence the value of the company with sig $0,000<\alpha=0.05$. Based on the results of the study, researchers suggest to companies 1 . To continue to increase the profits, so that will affect the increment of the firm value. 2. To be able to maintain its capital structure that also influences the value of the company. In addition, the company must also maintain the assets because with high assets will increase the value of $\ln$ total assets so that the higher the size of the company affects the value of the company.
\end{abstract}

Keywords : Profitability, Capital Structure, Firm Size, Firm Value

\begin{abstract}
Abstrak : Pokok persoalan yang dikaji dalam penelitian ini adalah pengaruh profitabilitas, struktur modal, dan ukuran perusahaan terhadap nilai perusahaan. Jenis penelitian yang digunakan adalah penelitian deskriptif. Populasi dalam penelitian ini seluruh perusahaan properti dan real estate yang terdaftar di Bursa Efek Indonesia. Teknik pengambilan sampel adalah purposive sampling sehingga terdapat 24 perusahaan yang dijadikan sampel. Data yang digunakan dalam penelitian ini merupakan data sekunder. Variabel dependen adalah nilai perusahaan sedangkan variabel independen profitabilitas, struktur modal, dan ukuran perusahaan. Model analisis yang digunakan adalah analisis regresi linier berganda. Dari hasil pengujian hipotesis didapat bahwa : Pertama, profitabilitas berpengaruh signifikan terhadap nilai perusahaan dengan nilai sig $0,000<\alpha=0,05$. Kedua, struktur modal berpengaruh terhadap nilai perusahaan dengan nilai sig $0,024<\alpha=0,05$. Ketiga, ukuran perusahaan berpengaruh terhadap nilai perusahaan dengan nilai sig 0,699 $>\alpha=0,05$. Keempat, profitabilitas, struktur modal, dan ukuran perusahaan berpengaruh signifikan terhadap nilai perusahaan dengan sig $0,000<\alpha=0,05$. Berdasarkan hasil penelitian, peneliti menyarankan kepada perusahaan 1 . Terus meningkatkan laba, sehingga akan mempengaruhi kenaikan nilai perusahaan. 2. Untuk dapat mempertahankan struktur permodalannya yang juga mempengaruhi nilai perusahaan. Selain itu, perusahaan juga harus menjaga aset karena dengan aset yang tinggi akan meningkatkan nilai pada total aset sehingga semakin tinggi ukuran perusahaan mempengaruhi nilai perusahaan.
\end{abstract}


Kata Kunci : Profitabilitas, Struktur Modal, Ukuran Perusahaan, Nilai Perusahaan

\section{PENDAHULUAN}

Persaingan dalam dunia bisnis dan ekonomi di era globalisasi yang semakin berkembang telah mendorong persaingan yang semakin ketat dan membuat perusahaan berusaha untuk meningkatkan nilai perusahaannya. Perusahaan dituntut untuk dapat bertahan dan bersaing dengan perusahaan dalam negeri, perusahaan asing, dan produk asing yang masuk ke dalam pasar dalam negeri. Persaingan dalam dunia bisnis dan ekonomi menyebabkan aspek keuangan perusahaan menjadi sangat penting dengan tujuan membangun dan menjamin kehidupan perusahaan.

Beberapa tahun terakhir Indonesia sedang mengalami pemantapan di seluruh sektor perekonomian. Kondisi tersebut sangat membuka peluang bagi dunia usaha untuk berkembang di berbagai sektor. Perusahaan property dan real estate adalah perusahaan yang menawarkan berbagai produk hasil dari pengembangan property yang berupa tanah dan bangunan.

Bisnis property dan real estate saat ini dimata masyarakat dinilai sangat menjanjikan karena harga property di Indonesia selalu meningkat setiap tahunnya. Kenaikan harga property di Indonesia disebabkan oleh pengaruh dari faktor supply dan demand, inflasi, dan tingkat pertumbuhan penduduk. Perkembangan tersebut menyebabkan perusahaan property dan real estate selalu mengalami kenaikan dan pertumbuhan setiap tahunnya. Kondisi pertumbuhan yang selalu mengalami kenaikan membuat kebutuhan sumber dana perusahaan property dan real estate akan meningkat.

Nilai perusahaan akan tercermin dari harga saham yang telah beredar dipasar saham. Harga saham merupakan indikator yang tepat untuk mengukur efektifitas perusahaan, maka semakin tinggi harga saham menunjukkan semakin efektif kinerja perusahaan dan akan meningkatkan nilai perusahaan. Dengan meningkatnya nilai perusahaan, maka akan semakin yakin investor untuk berinvestasi di perusahaan.

Menurut Maryam (2014), nilai perusahaan pula dipengaruhi oleh besar kecilnya profitabilitas yang dihasilkan oleh perusahaan. Profitabilitas mengukur kemampuan perusahaan untuk menghasilkan laba. Struktur modal menentukan penggunaan utang yang dilakukan oleh manajer keuangan untuk mendanai kegiatan perusahaan. Menurut Ustiani (2015), struktur modal adalah perimbangan jumlah utang jangka pendek yang bersifat permanen, utang jangka panjang, saham preferen dan saham biasa. Keputusan struktur modal (capital structure) meliputi pemilihan sumber dana baik yang berasal dari modal sendiri maupun modal asing dalam bentuk utang, kedua dana ini merupakan dana eksternal yang dapat mempengaruhi nilai perusahaan. Ukuran Perusahaan dianggap mampu memengaruhi nilai perusahaan. Karena semakin besar ukuran atau skala perusahaan, maka akan semakin mudah pula perusahaan memperoleh sumber pendanaan baik yang bersifat internal maupun eksternal.

\section{TELAAH KEPUSTAKAAN \\ Nilai Perusahaan}

Nilai perusahaan merupakan persepsi investor terhadap perusahaan, yang sering dikaitkan dengan harga saham. Harga saham yang tinggi membuat nilai perusahaan meningkat. Tujuan utama perusahaan menurut theory of the firm adalah untuk memaksimumkan kekayaan atau nilai perusahaan (value of the firm). Memaksimalkan nilai perusahaan sangat penting artinya bagi suatu perusahaan, karena dengan memaksimalkan nilai perusahaan berarti juga memaksimalkan kemakmuran pemegang saham yang merupakan tujuan utama perusahaan.

Keown (2010), mengemukakan bahwa nilai perusahaan merupakan nilai pasar atas surat berharga utang dan ekuitas perusahaan yang beredar. Nilai perusahaan merupakan persepsi investor terhadap tingkat keberhasilan perusahaan yang sering dikaitkan dengan harga saham.

Rasio penilaian memberikan informasi seberapa besar masyarakat menghargai perusahaan, sehingga masyarakat tertarik untuk membeli saham dengan harga yang lebih tinggi 
dibanding nilai bukunya. Berikut ini metode yang digunakan untuk mengukur nilai perusahaan pada penelitian ini. Price to Book Value (PBV) adalah rasio yang menunjukkan apakah harga saham yang diperdagangkan overvalued (di atas) atau undervalued (di bawah) nilai buku saham tersebut (Sartono, 2010).

Price to Book Value (PBV) menggambarkan seberapa besar pasar menghargai nilai buku saham suatu perusahaan. Makin tinggi rasio ini, berarti pasar percaya akan prospek perusahaan tersebut. PBV juga menunjukkan seberapa jauh suatu perusahaan mampu menciptakan nilai perusahaan yang relatif terhadap jumlah modal yang diinvestasikan.

$$
\mathrm{PBV}=\frac{\text { Market price per share }}{\text { Book value per share }}
$$

\section{Profitabilitas}

Profitabilitas merupakan kemampuan perusahaan dalam menghasilkan laba selama periode tertentu. Kinerja manajerial dari setiap perusahaan akan dapat dikatakan baik apabila tingkat profitabilitas perusahaan yang dikelolanya tinggi ataupun dengan kata lain maksimal, dimana profitabilitas ini umumnya selalu diukur dengan membandingkan laba yang diperoleh perusahaan dengan sejumlah perkiraan yang menjadi tolak ukur keberhasilan perusahaan seperti jumlah aktiva perusahaan maupun penjualan investasi, sehingga dapat diketahui efektifitas pengelolaan keuangan dan aktiva oleh perusahaan (Munawir, 2010).

Penelitian ini akan menghitung profitabilitas dengan Return on Equity (ROE). Return on Equity (ROE) merupakan suatu pengukuran dari penghasilan (income) yang tersedia bagi para pemilik perusahaan (baik pemegang saham biasa maupun pemegang saham preferen) atas modal yang mereka investasikan dalam perusahaan.

$$
\mathrm{ROE}=\frac{\text { Net Income }}{\text { Total Equity }}
$$

\section{Struktur Modal}

Struktur modal menurut Sawir (2004) ialah "Bauran sumber pendanaan permanen (jangka panjang) yang digunakan perusahaan". Sedangkan menurut Sartono (2010) "Struktur modal adalah merupakan perimbangan jumlah hutang jangka pendek yang bersifat permanen, hutang jangka panjang, saham preferen dan saham biasa". Dapat disimpulkan bahwa struktur modal adalah proporsi pendanaan perusahaan yang terdiri dari modal sendiri, hutang, saham biasa serta saham preferen guna membiayai operasional perusahaan jangka panjang.

Manajemen struktur modal bertujuan untuk menciptakan suatu bauran sumber dana permanen sedemikian rupa agar mampu memaksimalkan harga saham yang merupakan cermin dari nilai perusahaan. Nilai perusahaan akan naik apabila harga saham perusahaan tersebut juga naik. Dalam penelitian ini struktur modal dihitung dengan Debt to Assets Ratio (DAR).

$$
\mathrm{DAR}=\frac{\text { Total Liabilities }}{\text { Total Assets }}
$$

\section{Ukuran Perusahaan}

Ukuran perusahaan adalah suatu skala dimana dapat diklasifikasikan besar kecilnya perusahaan menurut berbagai cara antara lain dengan total aktiva, log size, nilai pasar saham, dan lain-lain. Besar kecilnya perusahaan akan memengaruhi kemampuan dalam menanggung risiko yang mungkin timbul dari berbagai situasi yang dihadapi perusahaan.

Ukuran perusahaan menggambarkan besar kecilnya suatu perusahaan yang dapat dinyatakan dengan total aset atau total penjualan bersih. Semakin besar total aset maupun penjualan maka semakin besar pula ukuran suatu perusahaan. Semakin besar aset maka semakin besar modal yang ditanam, sementara semakin banyak penjualan maka semakin banyak juga perputaran uang dalam perusahaan. Dengan demikian, ukuran perusahaan merupakan ukuran atau besarnya aset yang dimiliki oleh perusahaan. 


\section{METODOLOGI PENELITIAN}

\section{Jenis dan Periode Penelitian}

Data yang digunakan adalah data sekunder, yaitu data yang diperoleh secara tidak langsung atau melalui media perantara. Data tersebut bersifat kuantitatif mengenai laporan keuangan pada perusahaan property dan real estate pada tahun 2014-2018. Adapun sumber data pada penelitian ini diperoleh dari data laporan keuangan di Indonesia Stock Exchange (www.idx.co.id), bahan-bahan bacaan yang berhubungan dengan penelitian, jurnal-jurnal, dan karya-karya ilmiah.

\section{Populasi dan Sampel}

Menurut Sekaran (2014) "Populasi merupakan kumpulan semua elemen dalam populasi dimana sampel diambil". Populasi dalam penelitian ini adalah seluruh perusahaan property dan real estate yang telah terdaftar di Bursa Efek Indonesia dengan periode 2014 - 2018 yang sudah go public, karena setiap perusahaan yang telah go public mempunyai kepentingan untuk mempublikasikan serta menyajikan laporan keuangan perusahaan dengan tepat waktu dan telah sesuai dengan standar yang berlaku saat itu agar pengguna laporan keuangan tersebut dapat mengetahui kondisi yang ada pada perusahaan dan akan berpengaruh terhadap pengambilan keputusan.

\section{Sumber dan Pengumpulan Data}

Data yang digunakan untuk penelitian merupakan daya yang di peroleh dari website resmi Bursa Efek Indonesia (idx.co.id) dan informasid ari buku litetatur yang berkaitan dengan manajemen keuangan. Metode pengumpulan data pada penelitian ini menggunakan observasi dengan teknik dokumentasi. Teknik dokumentasi merupakan pelengkap dari penggunaan metode observasi. Pengumpulan data dilakukan dengan melihat dokumen yang telah terjadi (laporan keuangan dan laporan kinerja perusahaan) yang terdapat pada website Indonesia Stock Exchange.

\section{HASIL DAN PEMBAHASAN}

\section{Uji Regresi Secara Simultan (Uji F)}

Uji F atau Analysis of Variance (ANOVA) digunakan untuk mengetahui ada atau tidaknya pengaruh secara bersama-sama (simultan) variabel-variabel independen (bebas) terhadap variabel dependen (terikat). Hasil uji simultan menunjukkan bahwa nilai $\mathrm{F}$ hitung sebesar 19,944 dengan tingkat signifikansi 0,000, lebih kecil dari 0,05 yang berarti H0 ditolak dan H1 diterima, dapat dikatakan bahwa Profitabilitas, Struktur Modal, dan Ukuran Perusahaan secara bersama-sama memiliki pengaruh terhadap Nilai Perusahaan.

\section{Uji Regresi Secara Parsial (Uji t)}

Uji $t$ digunakan untuk mengetahui pengaruh masing-masing (parsial) variabel independen (bebas) terhadap variabel dependen (terikat). Untuk menguji hipotesis dilakukan pengujian secara parsial untuk melihat signifikansi dari pengaruh masing-masing variabel independen terhadap variabel dependen dengan mengasumsikan variabel lain adalah konstan.

\section{Pengaruh Profitabilitas $\left(X_{1}\right)$ Terhadap Nilai Perusahaan $(Y)$}

Berdasarkan hasil uji t, variabel profitabilitas memiliki koefisien $(\beta)$ sebesar 5,969 dengan nilai sig. sebesar 0,000 . Nilai signifikansi lebih kecil dari $\alpha=0,05$ atau $0,000<$ 0,05 . Nilai $\beta$ positif menunjukkan bahwa profitabilitas berpengaruh positif terhadap nilai perusahaan. Sehingga hipotesis yang menyatakan Profitabilitas berpengaruh positif terhadap Nilai Perusahaan diterima. Berdasarkan hasil pengujian, dapat disimpulkan bahwa profitabilitas berpengaruh positif terhadap nilai perusahan. 


\section{Pengaruh Struktur Modal $\left(\mathbf{X}_{2}\right)$ Terhadap Nilai Perusahaan (Y)}

Berdasarkan hasil uji t, variabel struktur modal memiliki koefisien $(\beta)$ sebesar 1,056 dengan nilai sig. sebesar 0,024 . Nilai signifikansi lebih kecil dari $\alpha=0,05$ atau 0,024 $<0,05$. Nilai $\beta$ positif menunjukkan bahwa struktur modal berpengaruh positif terhadap nilai perusahaan. Sehingga hipotesis yang menyatakan struktur modal berpengaruh positif terhadap Nilai Perusahaan diterima. Berdasarkan hasil pengujian, dapat disimpulkan bahwa struktur modal berpengaruh positif terhadap nilai perusahan.

\section{Pengaruh Ukuran Perusaahan ( $\left.X_{3}\right)$ Terhadap Nilai Perusahaan (Y)}

Berdasarkan hasil uji t, variabel ukuran perusahaan memiliki koefisien $(\beta)$ sebesar 0,021 dengan nilai sig. sebesar 0,699. Nilai signifikansi lebih besar dari $\alpha=0,05$ atau $0,699>0,05$. Nilai $\beta$ positif menunjukkan bahwa ukuran perusahaan berpengaruh positif terhadap nilai perusahaan. Sehingga hipotesis yang menyatakan ukuran perusahaan berpengaruh positif terhadap Nilai Perusahaan namun ditolak. Berdasarkan hasil pengujian, dapat disimpulkan bahwa ukuran perusahaan berpengaruh positif terhadap nilai perusahaan.

\section{KESIMPULAN DAN SARAN Kesimpulan}

Penelitian ini dilakukan untuk menganalisis pengaruh profitabilitas (ROE), struktur modal (DAR), dan ukuran perusahaan (InTA) terhadap nilai perusahaan (PBV). Sampel yang digunakan dalam penelitian ini sejumlah 24 perusahaan property dan real estate yang terdaftar di Bursa Efek Indonesia periode 2014 - 2018. Dengan total seluruh observasi 120 data. Teknik analisis yang digunakan dalam penelitian ini adalah uji data panel dengan menggunakan program SPSS 24. berdasarkan hasil penelitian yang telah dilakukan, maka dapat ditarik kesimpulan sebagai berikut,

1. Profitabilitas memiliki pengaruh positif dan signifikan terhadap nilai perusahaan. Hal ini dibuktikan dengan semakin tinggi profitabilitas, maka semakin tinggi nilai perusahaan.

2. Struktur modal memiliki pengaruh positif terhadap nilai perusahaan. Hal ini dibuktikan dengan semakin rendah struktur modal, maka nilai perusahaan semakin tinggi

3. Ukuran perusahaan tidak memiliki pengaruh terhadap nilai perusahaan. Hal ini dibuktikan dengan semakin tinggi ukuran perusahaan, maka nilai perusahaan akan semakin tinggi.

4. Profitabilitas, struktur modal, keputusan investasi, dan ukuran perusahaan secara simultan berpengaruh signifikan terhadap nilai perusahaan.

\section{Saran}

Berdasarkan hasil penelitian yang diperoleh dalam penelitian ini maka diharapkan dapat memberikan masukan atau saran bagi akkademisi, perusahaan dan pemangku kepentingan, maka saran yang dapat diberikan sebagai berikut.

1. Bagi akademisi dan peneliti

Bagi akademisi dan peneliti selanjutnya yang tertarik untuk melakukan penelitian serupa, jangan hanya membatasi pada perusahaan yang bergerak di sektor property dan real estate yang terdaftar di BEI. Selain itu, disarankan juga untuk menambah jumlah data dengan memperpanjang periode penelitian serta menggunakan sampel dari jenis perusahaan lain sebagai tambahan referensi. Disamping menambah jumlah data penelitian, peneliti juga menyarankan bagi para peneliti selanjutnya untuk dapat menambahkan variabel-variabel yang dinilai memengaruhi nilai perusahaan.

2. Bagi Perusahaan

Bagi perusahaan, informasi yang diperoleh dari penelitian ini sebaiknya dapat digunakan sebagai bahan pertimbangan dalam mengambil keputusan dalam rangka meningkatkan nilai perusahaan agar mampu menarik minat investor untuk menanamkan saham di 
perusahaan tersebut. Kemudian perusahaan dapat menjadikan hasil penelitian iini sebagai bahan referensi dalam meningkatkan nilai perusahaan yaitu engan lebih memperhatikan variabel-variabel yang berpengaruh terhadap nilai perusahaan dalam hasil penelitian ini dalam mengelola kinerja keuangan perusahaan dimasa yang akan dating

3. Bagi investor dan calon investor

Bagi investor dan calon investor yang ingin menginvestasikan dananya ke perusahaan yang go public khususnya di bidang property dan real estate, maka diharapkan penelitian ini dapat dijadikan referensi dan sebagai bahan pertimbangan untuk mengambil keputusan dalam berinvestasi. Yaitu dengan menganalisis keputusan keuangan yang diambil manajemen perusahaan pada periode terdahulu hingga sekarang (update), yang dicerminkan dari perhitungan nilai perusahaan (PBV), profitabilitas (ROE), struktur modal (DAR), dan ukuran perusahaan $(\operatorname{lnTA})$ perusahaan yang akan dijadikan wadah berinvestasi.

\section{DAFTAR PUSTAKA}

Keown, JA., dkk. 2010. Manajemen Keuangan: Prinsip dan Penerapan Jilid 1. 10th ed. Jakarta: Penerbit Indeks.

Maryam, Siti. 2014. Analisis Pengaruh Firm Size, Growth, Leverage dan Profitabilitas terhadap Nilai Perusahaan (Studi pada Perusahaan Manufaktur yang Terdaftar di Bursa Efek Indonesia). Makasar: Universitas Hasanuddin.

Munawir, S. 2010. Analisis Laporan Keuangan. 4th ed. Yogyakarta: Liberty.

Sawir, Agnes. 2004, Kebijakan Pendanaan dan Restrukturisasi Perusahaan. Jakarta : Gramedia Pustaka Utama

Sekaran, Uma. 2014. Metodologi Penelitian Untuk Bisnis I. 4th ed. Jakarta: Penerbit Salemba Empat.

Sartono, Agus. 2010. Manajemen Keuangan Teori dan Aplikasi. 4th ed. Yogyakarta : BPFE.

Ustiani, Nila. 2015. Pengaruh Struktur Modal, Kepemilikan Manajerial, Keputusan Investasi, Kebijakan Dividen Keputusan Pendanaan, dan Profitabilitas terhadap Nilai Perusahaan (Studi pada Perusahaan Keuangan dan Perbankan di BEI Tahun 2009 2013). Jurnal Ilmiah Mahasiswa Akuntansi Universitas Pandanaran Vol. 1, No. 1. 